\title{
Antiproliferative Sorbicillinoids From the Deep-Sea-Derived Penicillium allii-sativi
}

\section{OPEN ACCESS}

Edited by:

Peng Fu,

Ocean University of China, China

Reviewed by:

Yonghong Liu,

Chinese Academy of Sciences (CAS),

China

Junfeng Wang,

Chinese Academy of Sciences, China

Fandong Kong,

Chinese Academy of Tropical

Agricultural Sciences, China

*Correspondence:

Hai-Feng Chen

haifeng@xmu.edu.cn

Xian-Wen Yang

yangxianwen@tio.org.cn

Xiao-Kun Zhang

xkzhang@xmu.edu.cn

tThese authors have contributed equally to this work

Specialty section:

This article was submitted to Microbial Physiology and Metabolism, a section of the journal Frontiers in Microbiology

Received: 02 December 2020 Accepted: 30 December 2020 Published: 21 January 2021

Citation:

Xie C-L, Zhang D, Lin T, He Z-H, Yan Q-X, Cai Q, Zhang X-K, Yang X-W and Chen H-F (2021)

Antiproliferative Sorbicillinoids

From the Deep-Sea-Derived

Penicillium allii-sativi.

Front. Microbiol. 11:636948

doi: 10.3389/fmicb.2020.636948

\author{
Chun-Lan Xie ${ }^{1,2 \dagger}$, Duo Zhang ${ }^{1 \dagger}$, Ting Lin ${ }^{1}$, Zhi-Hui He ${ }^{2}$, Qing-Xiang Yan' ${ }^{2}$, Qi Cai', \\ Xiao-Kun Zhang ${ }^{1 *}$, Xian-Wen Yang ${ }^{2 *}$ and Hai-Feng Chen ${ }^{1 *}$
}

\begin{abstract}
${ }^{1}$ School of Pharmaceutical Sciences, Xiamen University, Xiamen, China, ${ }^{2}$ Key Laboratory of Marine Biogenetic Resources, Third Institute of Oceanography, Ministry of Natural Resources, Xiamen, China
\end{abstract}

Two new (1-2) and three known (3-5) sorbicillinoids were isolated from the deep-seaderived fungus Penicillium allii-sativi MCCC 3A00580. Compounds $\mathbf{1}$ and $\mathbf{2}$, named sorbicatechols $\mathrm{C}$ and $\mathrm{D}$, were two new hybrid dihydrosorbillinoids. Their structures were established mainly by spectroscopic analyses and electronic circular dichroism (ECD) calculations. All five isolates were tested for antiproliferative activities against four tumor cell lines of MCF-7, HT-29, HuH-7, and LNCap. Compounds 2 and $\mathbf{5}$ inhibited HT-29 cells in a good dose-dependent manner. Mechanism investigation uncovered that they could significantly induce cell cycle G2-M phase arresting by increasing the protein levels of $\mathrm{p}-\mathrm{H} 3$ and cyclin B1.

Keywords: deep-sea, fungi, sorbicillinoids, cell cycle, cytotoxicities

\section{INTRODUCTION}

Sorbicillinoids are hexaketide metabolites that possess complex and highly oxygenated frameworks. Structurally, they can be divided into four groups: monomeric, dimeric, trimeric, and hybrid sorbicillinoids (Harned and Volp, 2011; Meng et al., 2016). The unique structural features of the sorbicillinoids make them attractive candidates for developing new pharmaceutical and agrochemical agents (Abe et al., 2000, 2001; Fahad et al., 2013; Meng et al., 2019; Kahlert et al., 2020). Up to now, around 100 sorbicillinoids have been reported from fungi, especially marine Penicillium (Meng et al., 2016). During our ongoing search for structurally novel and biologically interesting secondary metabolites from deep-sea-derived microorganisms (Yang et al., 2013; Niu et al., 2017, 2020; Xie et al., 2019a), the rice static fermentation extract of Penicillium allii-sativi MCCC 3A00580 exhibited potent in vitro antitumor activity. Previously, three meroterpenoids were obtained and andrastones A showed significant inhibitory effect against HepG2 tumor cells by activating caspase- 3 and regulating the transcriptional activation function of RXR $\alpha$ (Xie et al., 2019b). Further investigation on this strain led to the discovery of two new and three known sorbicillinoid derivates (Figure 1). Structurally, compounds 1 and $\mathbf{2}$ are two novel hybrid dihydrosorbicillinoids. All isolates were tested for antiproliferative bioactivities, compounds $\mathbf{2}$ and $\mathbf{5}$ could inhibit HT-29 tumor cells in a good dose-dependent manner. Herein, we report the isolation, structures, and bioactivities of these compounds. 

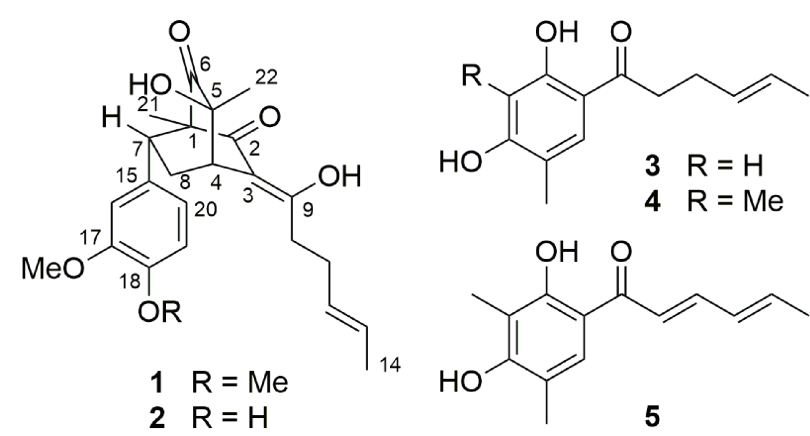

FIGURE 1 | Compounds 1-5 from Penicillium allii-sativi MCCC 3A00580.

\section{MATERIALS AND METHODS}

\section{General Experimental Procedures}

The NMR spectra were recorded on a Bruker $400 \mathrm{MHz}$ spectrometer using TMS as an internal standard. The high resolution electrospray ionization mass spectroscopy (HRESIMS) spectra were measured on a Waters Xevo G2 Q-TOF (Waters) mass spectrometer. Optical rotations were measured with an Anton Paar MCP100 polarimeter. Electronic circular dichroism (ECD) spectra were measured on a JASCO J-715 spectropolarimeter. TLC and column chromatography (CC) were performed on plates precoated with silica gel GF254 $(10-40 \mu \mathrm{m})$ or over silica gel (200-300 mesh, Qingdao Marine Chemical Factory). Chromatography was performed using Sephadex LH-20 (18-110 $\mu \mathrm{m}$, Amersham Pharmacia Biotech AB), and octadecylsilane (ODS) silica gel (50 $\mu \mathrm{m}$, Daiso). The preparative and semipreparative HPLC were performed on an Agilent Technologies 1,260 infinity instrument equipped with the DAD detector. Anti- $\beta$-actin (Cat. 4970S), anti-p-H3 (Cat. 3,377), and anti-Cyclin B1 (Cat. 12231S) antibodies were all purchased from Cell Signaling Technology (Boston, MA, United States).

\section{Fermentation, Extraction, and Isolation}

Penicillium allii-sativi was isolated from the western Pacific Ocean $(-4,302 \mathrm{~m})$. The identification and fermentation of the fungus were reported previously (Xie et al., 2019b). As a result, a defatted extract $(60.4 \mathrm{~g})$ was obtained, which was subjected to $\mathrm{CC}$ over silica gel with gradient $\mathrm{CH}_{2} \mathrm{Cl}_{2}-\mathrm{MeOH}$ to get eight fractions (Fr.1-Fr.8). Fraction Fr.3 (5.5 g) was further purified by CC on ODS using a gradient $\mathrm{H}_{2} \mathrm{O}-\mathrm{MeOH}$ to yield three subfractions (Fr.3.1-Fr.3.3). Compounds 1 $(23.2 \mathrm{mg})$ and $2(4.5 \mathrm{mg})$ were obtained from subfraction Fr.3.2 (211.4 mg) by repeated CC over silica gel CC (PE-EtOAc, 3:1) and Sephadex LH-20 (MeOH). While compound $3(4.4 \mathrm{mg})$ was obtained from subfraction Fr.3.3 (150.6 mg) by CC over silica gel $\left(\mathrm{CH}_{2} \mathrm{Cl}_{2}-\mathrm{MeOH}, 50: 1\right)$ and Sephadex LH-20 (MeOH). Fraction Fr.8 $(15 \mathrm{~g})$ was subjected subsequently to $\mathrm{CC}$ over ODS $\left(\mathrm{MeOH}-\mathrm{H}_{2} \mathrm{O}: 5 \% \rightarrow 100 \%\right)$ and silica gel $\left(\mathrm{CH}_{2} \mathrm{Cl}_{2}-\mathrm{MeOH}\right.$, $30: 1)$ to get compounds $4(20.3 \mathrm{mg})$ and $5(16.5 \mathrm{mg})$.

Sorbicatechol C (1): yellow oil; $[\alpha]_{\mathrm{D}}^{20}-14.6($ c $0.50, \mathrm{MeOH}),-7.2$ (c 0.50, $\left.\mathrm{CHCl}_{3}\right)$; UV $\left(\mathrm{CH}_{3} \mathrm{OH}\right) \lambda_{\max }(\log \varepsilon) 257$ (3.24), 288
TABLE 1 | ${ }^{1} \mathrm{H}$ and ${ }^{13} \mathrm{C}$ NMR spectroscopic data for compounds $\mathbf{1}$ and $\mathbf{2}$ in DMSO- $d_{6}$.

\begin{tabular}{|c|c|c|c|c|}
\hline \multirow[t]{2}{*}{ No } & \multicolumn{2}{|c|}{1} & \multicolumn{2}{|c|}{2} \\
\hline & $\delta_{\mathrm{c}}$ & $\delta_{\mathrm{H}}(J$ in $\mathrm{Hz})$ & $\delta_{\mathrm{C}}$ & $\delta_{\mathrm{H}}(\boldsymbol{J}$ in $\mathrm{Hz})$ \\
\hline 1 & $64.1 \mathrm{C}$ & & $64.2 \mathrm{C}$ & \\
\hline 2 & $196.0 \mathrm{C}$ & & $196.0 \mathrm{C}$ & \\
\hline 3 & $112.5 \mathrm{C}$ & & $112.5 \mathrm{C}$ & \\
\hline 4 & $41.1 \mathrm{CH}$ & 3.15 t (2.8) & $41.1 \mathrm{CH}$ & 3.12 t (2.6) \\
\hline 5 & $72.9 \mathrm{C}$ & & $72.9 \mathrm{C}$ & \\
\hline 6 & 209.6 C & & $209.6 \mathrm{C}$ & \\
\hline 7 & $45.3 \mathrm{CH}$ & 3.11 dd $(10.6,5.8)$ & $45.4 \mathrm{CH}$ & $3.05 \mathrm{dd}(10.6,5.8)$ \\
\hline 8 (a) & $31.3 \mathrm{CH}_{2}$ & $\begin{array}{l}2.90 \text { ddd (13.2, } \\
10.6,2.8)\end{array}$ & $31.4 \mathrm{CH}_{2}$ & $\begin{array}{l}2.88 \text { ddd (13.4, } \\
10.6,2.8)\end{array}$ \\
\hline (b) & & $\begin{array}{l}1.70 \text { ddd (13.2, } \\
5.8,2.8)\end{array}$ & & $\begin{array}{l}1.68 \text { ddd (13.4, } \\
5.8,2.8)\end{array}$ \\
\hline 9 & $178.7 \mathrm{C}$ & & $178.6 \mathrm{C}$ & \\
\hline 10 (a) & $31.5 \mathrm{CH}_{2}$ & $2.67 \mathrm{dt}(14.0,7.5)$ & $31.5 \mathrm{CH}_{2}$ & $2.65 \mathrm{dt}(14.0,7.0)$ \\
\hline (b) & & $2.48 \mathrm{dt}(14.0,6.7)$ & & $2.45 \mathrm{dt}(14.0,6.6)$ \\
\hline 11 & $28.9 \mathrm{CH}_{2}$ & $2.32 \mathrm{~m}$ & $28.9 \mathrm{CH}_{2}$ & $2.33 \mathrm{~m}$ \\
\hline 12 & $129.6 \mathrm{CH}$ & 5.49 m (overlap) & $129.6 \mathrm{CH}$ & 5.47 m (overlap) \\
\hline 13 & $125.9 \mathrm{CH}$ & 5.49 m (overlap) & $125.9 \mathrm{CH}$ & 5.49 m (overlap) \\
\hline 14 & $17.7 \mathrm{CH}_{3}$ & $1.56 \mathrm{~d}(4.7)$ & $17.7 \mathrm{CH}_{3}$ & $1.57 \mathrm{~d}(4.7)$ \\
\hline 15 & $134.3 \mathrm{C}$ & & $132.8 \mathrm{C}$ & \\
\hline 16 & $111.6 \mathrm{CH}$ & $6.53 \mathrm{~d}(1.5)$ & $112.1 \mathrm{CH}$ & $6.49 \mathrm{~d}(1.8)$ \\
\hline 17 & $148.3 \mathrm{C}$ & & $147.2 \mathrm{C}$ & \\
\hline 18 & $147.8 \mathrm{C}$ & & $145.5 \mathrm{C}$ & \\
\hline 19 & $111.6 \mathrm{CH}$ & $6.83 \mathrm{~d}(8.2)$ & $115.2 \mathrm{CH}$ & $6.63 d(8.1)$ \\
\hline 20 & $120.2 \mathrm{CH}$ & $6.51 \mathrm{dd}(8.2,1.5)$ & $120.6 \mathrm{CH}$ & $6.37 \mathrm{dd}(8.1,1.8)$ \\
\hline 21 & $10.7 \mathrm{CH}_{3}$ & $0.71 \mathrm{~s}$ & $10.7 \mathrm{CH}_{3}$ & $0.70 \mathrm{~s}$ \\
\hline 22 & $23.6 \mathrm{CH}_{3}$ & $1.13 \mathrm{~s}$ & $23.6 \mathrm{CH}_{3}$ & $1.14 \mathrm{~s}$ \\
\hline 17-OMe & $55.1 \mathrm{CH}_{3}$ & $3.64 \mathrm{~s}$ & $55.3 \mathrm{CH}_{3}$ & $3.65 \mathrm{~s}$ \\
\hline 18-OMe & $55.4 \mathrm{CH}_{3}$ & $3.70 \mathrm{~s}$ & & \\
\hline $5-\mathrm{OH}$ & & $5.98 \mathrm{~s}$ & & $5.96 \mathrm{~s}$ \\
\hline $9-\mathrm{OH}$ & & 14.68 br s & & $14.69 \mathrm{br} s$ \\
\hline $18-\mathrm{OH}$ & & & & $8.92 \mathrm{~s}$ \\
\hline
\end{tabular}

(3.61) nm; ECD $(\mathrm{MeOH}) \lambda_{\max }(\Delta \varepsilon) 201(-4.63), 231(+0.68)$, $297(-3.29), 337(+1.77) \mathrm{nm} ;{ }^{1} \mathrm{H}$ and ${ }^{13} \mathrm{C}$ NMR data, see Table 1; HRESIMS $m / z 437.1951[\mathrm{M}+\mathrm{Na}]^{+}$(calcd for $\mathrm{C}_{24} \mathrm{H}_{30} \mathrm{O}_{6} \mathrm{Na}$, 437.1940), $413.1958[\mathrm{M}-\mathrm{H}]^{-}$(calcd for $\mathrm{C}_{24} \mathrm{H}_{29} \mathrm{O}_{6}, 413.1964$ ).

Sorbicatechol D (2): yellow oil; $[\alpha] 20 \mathrm{D}-19.1(c 0.35, \mathrm{MeOH})$; UV (Me) $\lambda_{\max }(\log \varepsilon) 268(2.42), 286(2.50) \mathrm{nm} ; \mathrm{ECD}(\mathrm{MeOH})$ $\lambda_{\max }(\Delta \varepsilon) 230(-0.87), 231(+2.24), 296(-12.30), 335(+11.58)$ $\mathrm{nm} ;{ }^{1} \mathrm{H}$ and ${ }^{13} \mathrm{C}$ NMR data, see Table 1; HRESIMS $m / z 399.1790$ $[\mathrm{M}-\mathrm{H}]^{-}$(calcd for $\mathrm{C}_{23} \mathrm{H}_{27} \mathrm{O}_{6}, 399.1808$ ).

\section{ECD Calculation}

As reported previously (Niu et al., 2020), conformational analyses were carried out via random searching in the Sybyl-X 2.0 using the MMFF94S force field with an energy cutoff of $2.0 \mathrm{kcal} /$ mol. Subsequently, the lowest energy conformer was re-optimized using DFT at b3lyp/6-31+g(d,p) level in MeOH by the GAUSSIAN 09 program. The energies, oscillator strengths, and rotational strengths (velocity) of the first 30 electronic excitations were calculated using the TDDFT methodology at the cam-b3lyp/ TZVP level using the polarizable continuum model in $\mathrm{MeOH}$. The ECD spectrum were simulated by the overlapping Gaussian function (half the bandwidth at $1 / \mathrm{e}$ peak height, $\sigma=0.35$, UV correction $=23 \mathrm{~nm}$ ). 


\section{Antiproliferative Bioassay}

Briefly, four cancer cell lines of breast cancer cells (MCF-7), colon cancer cells (HT-29), hepatoma cells (HuH-7), and prostate cancer cells (LNCap) were treated with different concentrations of compounds 1-5 for $48 \mathrm{~h}$. The cell viability was evaluated using MTT assay.

\section{Cell Cycle Experiment}

HT-29 cells were treated with tested compounds. After 48 h, they were collected by trypsin and dehydrated with $70 \% \mathrm{EtOH}$ overnight at $4{ }^{\circ} \mathrm{C}$. After alcohol was removed, cells were washed twice using PBS and were labeled by DAPI (1:10000 dilution in PBS, D8417 from Sigma-Aldrich, Saint Louis, MO, United States) for $10 \mathrm{~min}$. Finally, fluorescence was measured by flow cytometry using PB450-A (CytoFLEX, Beckman Coulter, Kraemer Boulevard Brea, CA, United States).

\section{Western Blotting}

Cell lysates were boiled in sodium dodecyl sulfate (SDS) sample loading buffer, resolved by $10 \%$ SDS-polyacrylamide gel electrophoresis (SDS-PAGE) and transferred to nitrocellulose. The membranes were blocked in $5 \%$ milk in Tris-buffered saline and Tween 20 [TBST; $10 \mathrm{mM}$ Tris- $\mathrm{HCl}$ (pH 8.0), $150 \mathrm{mM}$ $\mathrm{NaCl}$, and $0.05 \%$ Tween 20] for $1 \mathrm{~h}$ at room temperature. After washing twice with TBST, the membranes were incubated with appropriate primary antibodies in TBST for $1 \mathrm{~h}$ and then washed twice, probed with horseradish peroxide-linked anti-immunoglobulin (1:5000 dilution) for $1 \mathrm{~h}$ at room temperature. After three washes with TBST, immunoreactive products were visualized using enhanced chemiluminescence reagents and autoradiography.

\section{RESULTS AND DISCUSSION}

Compound $\mathbf{1}$ was isolated as a yellow oil. The sodiated molecular ion peak at $\mathrm{m} / z$ 495.1951 $[\mathrm{M}+\mathrm{Na}]^{+}$in the HRESIMS indicated its molecular formula as $\mathrm{C}_{24} \mathrm{H}_{30} \mathrm{O}_{6}$, requiring 10 degrees of unsaturation. The ${ }^{1} \mathrm{H}$ NMR spectrum showed two methyl singlets $\left[\delta_{\mathrm{H}} 0.71(3 \mathrm{H}, \mathrm{s}, \mathrm{Me}-21), 1.13(3 \mathrm{H}, \mathrm{s}, \mathrm{Me}-22)\right]$, one methyl doublet $\left[\delta_{\mathrm{H}} 1.56(3 \mathrm{H}, \mathrm{d}, J=4.7 \mathrm{~Hz}, \mathrm{Me}-14)\right]$, three typical ABX aromatic protons $\left[\delta_{\mathrm{H}} 6.51(1 \mathrm{H}, \mathrm{dd}, J=8.2,1.5 \mathrm{~Hz}, \mathrm{H}-20), 6.53(1 \mathrm{H}, \mathrm{d}\right.$, $J=1.5 \mathrm{~Hz}, \mathrm{H}-16), 6.83(1 \mathrm{H}, \mathrm{d}, J=8.2 \mathrm{~Hz}, \mathrm{H}-19)]$, and two methoxyls $\left[\delta_{\mathrm{H}} 3.64(3 \mathrm{H}, \mathrm{s}, 17-\mathrm{OMe}), 3.70(3 \mathrm{H}, \mathrm{s}, 18-\mathrm{OMe})\right]$. The ${ }^{13} \mathrm{C}$ NMR spectrum indicated 24 carbon resonances including three methyls $\left(\delta_{\mathrm{C}} 10.7,17.7\right.$, and 23.6), three methylenes, seven methines (two olefinic and three aromatic), nine quaternary carbons (two ketones at $\delta_{\mathrm{C}} 196.0$ and 209.6, two olefinic at $\delta_{\mathrm{C}}$ 112.5 and 178.7, and three aromatic at $\delta_{\mathrm{C}} 134.3,147.8$, and 148.3), and two methoxyls. Since the ABX aromatic moiety, two ketones, and the other four olefinic carbons accounted for eight unsaturations, compound $\mathbf{1}$ was deduced to be a bicyclic molecule. In the ${ }^{1} \mathrm{H}-{ }^{1} \mathrm{H}$ COSY spectrum, two segments could easily be deduced on the basis of correlations of $\mathrm{H}_{2}-8$ to $\mathrm{H}-4 / \mathrm{H}-7$ and Me-14 via $\mathrm{H}-12 / \mathrm{H}-13$ to $\mathrm{H}_{2}-11 / \mathrm{Hab}-10$ (Figure 2). These two segments along with the $\mathrm{ABX}$ aromatic moiety could

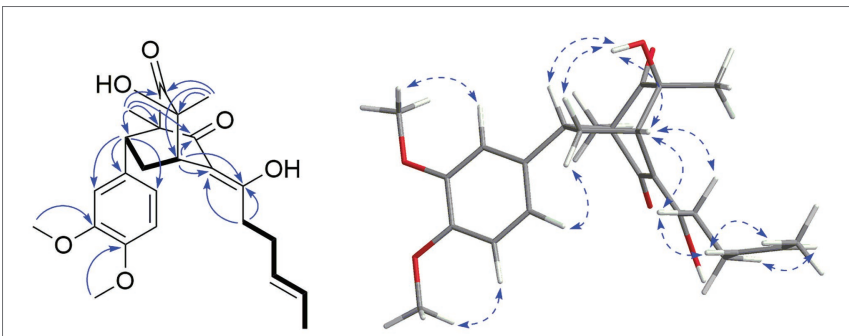

FIGURE 2 | The Key COSY ( $)$, HMBC $(\curvearrowleft)$, and NOESY $\left(\boldsymbol{r}^{-} \mathbf{V}\right)$ correlations of compound $\mathbf{1}$

be connected by the HMBC correlations of Me-21 to C-1 $\left(\delta_{\mathrm{C}}\right.$ $64.1 \mathrm{~s}) / \mathrm{C}-2\left(\delta_{\mathrm{C}} 196.0 \mathrm{~s}\right) / \mathrm{C}-6\left(\delta_{\mathrm{C}} 209.6 \mathrm{~s}\right) / \mathrm{C}-7\left(\delta_{\mathrm{C}} 45.3 \mathrm{~d}\right), \mathrm{Me}-22$ to $\mathrm{C}-4\left(\delta_{\mathrm{C}} 41.1 \mathrm{~d}\right) / \mathrm{C}-5\left(\delta_{\mathrm{C}} 72.9 \mathrm{~s}\right) / \mathrm{C}-6, \mathrm{H}-4\left(\delta_{\mathrm{H}} 3.15, \mathrm{t}, J=2.8 \mathrm{~Hz}\right)$ to $\mathrm{C}-2 / \mathrm{C}-3\left(\delta_{\mathrm{C}} 112.5 \mathrm{~s}\right) / \mathrm{C}-9\left(\delta_{\mathrm{C}} 178.7 \mathrm{~s}\right), \mathrm{H}-7\left(\delta_{\mathrm{H}} 3.11, \mathrm{dd}\right.$, $J=10.6,5.8 \mathrm{~Hz})$ to $\mathrm{C}-15\left(\delta_{\mathrm{C}} 134.3 \mathrm{~s}\right) / \mathrm{C}-16\left(\delta_{\mathrm{C}} 111.6 \mathrm{~d}\right) / \mathrm{C}-20$ $\left(\delta_{\mathrm{C}} 120.2 \mathrm{~d}\right), \operatorname{Hab}-10\left(\delta_{\mathrm{H}} 2.67, \mathrm{dt}, J=14.0,7.5 \mathrm{~Hz} ; 2.48, \mathrm{dt}\right.$, $J=14.0,6.7 \mathrm{~Hz})$ to $\mathrm{C}-3 / \mathrm{C}-9,17-\mathrm{OMe}$ to $\mathrm{C}-17\left(\delta_{\mathrm{C}} 148.3 \mathrm{~s}\right)$, and $18-\mathrm{OMe}$ to $\mathrm{C}-18\left(\delta_{\mathrm{C}} 147.8 \mathrm{~s}\right)$. Accordingly, the planar structure of compound $\mathbf{1}$ was established as a sorbicillinoid derivate, structurally related to sorbicatechol A. In the NOESY spectrum, $5-\mathrm{OH}\left(\delta_{\mathrm{H}} 5.98 \mathrm{~s}\right)$ was correlated to $\mathrm{H}-7\left(\delta_{\mathrm{H}} 3.11\right.$, dd, $J=10.6,5.8 \mathrm{~Hz}) / \mathrm{Ha}-8\left(\delta_{\mathrm{H}} 2.90\right.$, ddd, $\left.J=13.2,10.6,2.8 \mathrm{~Hz}\right)$, while $\mathrm{Hb}-8\left(\delta_{\mathrm{H}} 1.70\right.$, ddd, $\left.J=13.2,5.8,2.8 \mathrm{~Hz}\right)$ was correlated to $\mathrm{H}-16 / \mathrm{H}-20$. This suggested co-plane of $\mathrm{H}-7$ and $5-\mathrm{OH}$. Furthermore, correlations of Hab-10 $\left(\delta_{\mathrm{H}} 2.67, \mathrm{dt}, J=14.0,7.5 \mathrm{~Hz}\right.$, $\mathrm{Ha}-10 ; 2.48, \mathrm{dt}, J=14.0,6.7 \mathrm{~Hz}, \mathrm{Hb}-10)$ to $\mathrm{H}-4 / \mathrm{H}-12(\mathrm{H}-13)$ deduced the Z-orientation of the olefinic bonds of C-3/C-9. Since the chemical shifts of $\mathrm{H}-12$ and $\mathrm{H}-13$ were overlapped, it was impossible to assign the configuration by their coupling constants. However, the NOESY correlations of Me-14 to H-12(H13) but not $\mathrm{H}_{2}-11$ could suggest the $E$-orientation of $\mathrm{C}-12 / \mathrm{C}-13$. On the basis of the above evidences, the relative configuration of compound 1 was, therefore, determined undoubtedly.

To further assign its absolute stereochemistry, the theoretical calculation of the electronic circular dichroism (ECD) was conducted. As shown in Figure 3, the experimental ECD spectrum of compound $\mathbf{1}$ showed the same Cotton effects as those of $1 R, 4 S, 5 S, 7 R-\mathbf{1} \quad$ (1a). Therefore, the absolute stereochemistry of compound $\mathbf{1}$ was assigned as 10,11-dihydrosorbicatechol A, and named sorbicatechol C.

Compound 2 was also isolated as a yellow oil. The molecular formula was assigned as $\mathrm{C}_{23} \mathrm{H}_{28} \mathrm{O}_{6}$ on the basis of the HRESIMS at $m / z 399.1790[\mathrm{M}-\mathrm{H}]^{-}$(calcd for $\left.\mathrm{C}_{23} \mathrm{H}_{27} \mathrm{O}_{6}, 399.1808\right)$. The ${ }^{1} \mathrm{H}$ and ${ }^{13} \mathrm{C}$ NMR spectroscopic data (Table 1) indicated 23 carbon resonances including two methyl singlets, one methyl doublet, three methylenes, seven methines (two olefinic and three aromatic), nine quaternary carbons (two ketones at $\delta_{\mathrm{C}}$ 196.0 and 209.6, two olefinics at $\delta_{\mathrm{C}} 112.5$ and 178.6, and three aromatics at $\delta_{\mathrm{C}} 132.8,145.5$, and 147.2), and one methoxyl. These signals were very similar to those of compound $\mathbf{1}$, except that the methoxyl group at the $\mathrm{C}-18$ position in compound $\mathbf{1}$ was changed to a hydroxy moiety in compound 2 . This was evidenced by an additional hydroxy unit and the absence of a methoxyl group in compound 2. Further confirmation could 


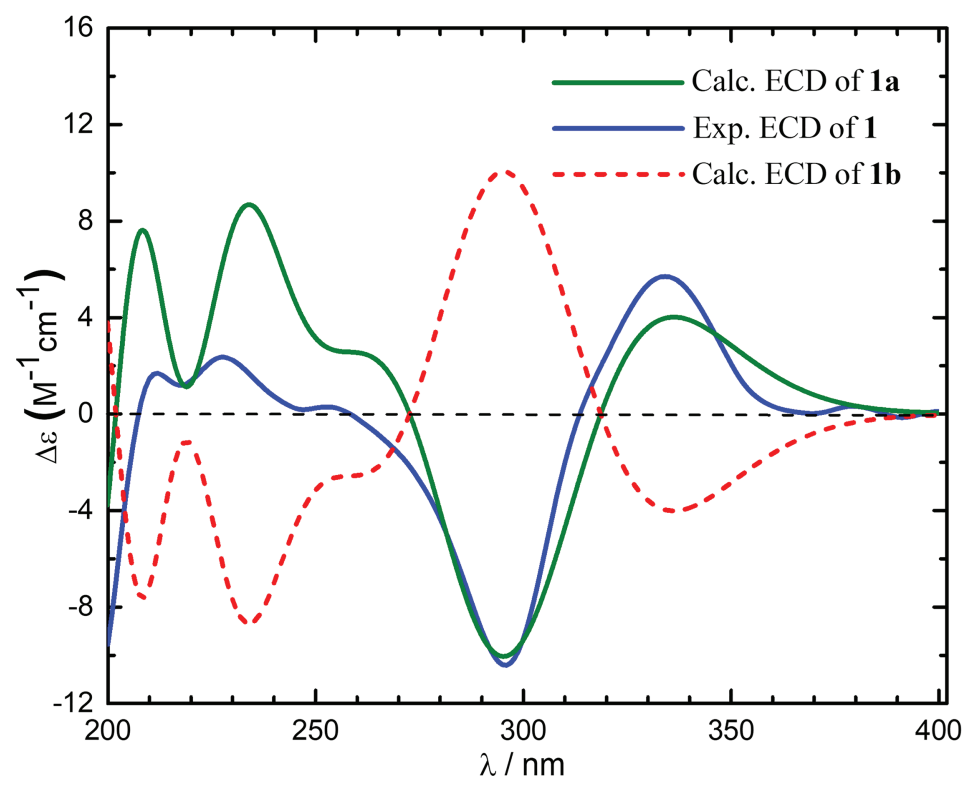

FIGURE 3 | Experimental and calculated electronic circular dichroism (ECD) spectra of compound $\mathbf{1}$ in $\mathrm{MeOH}$.
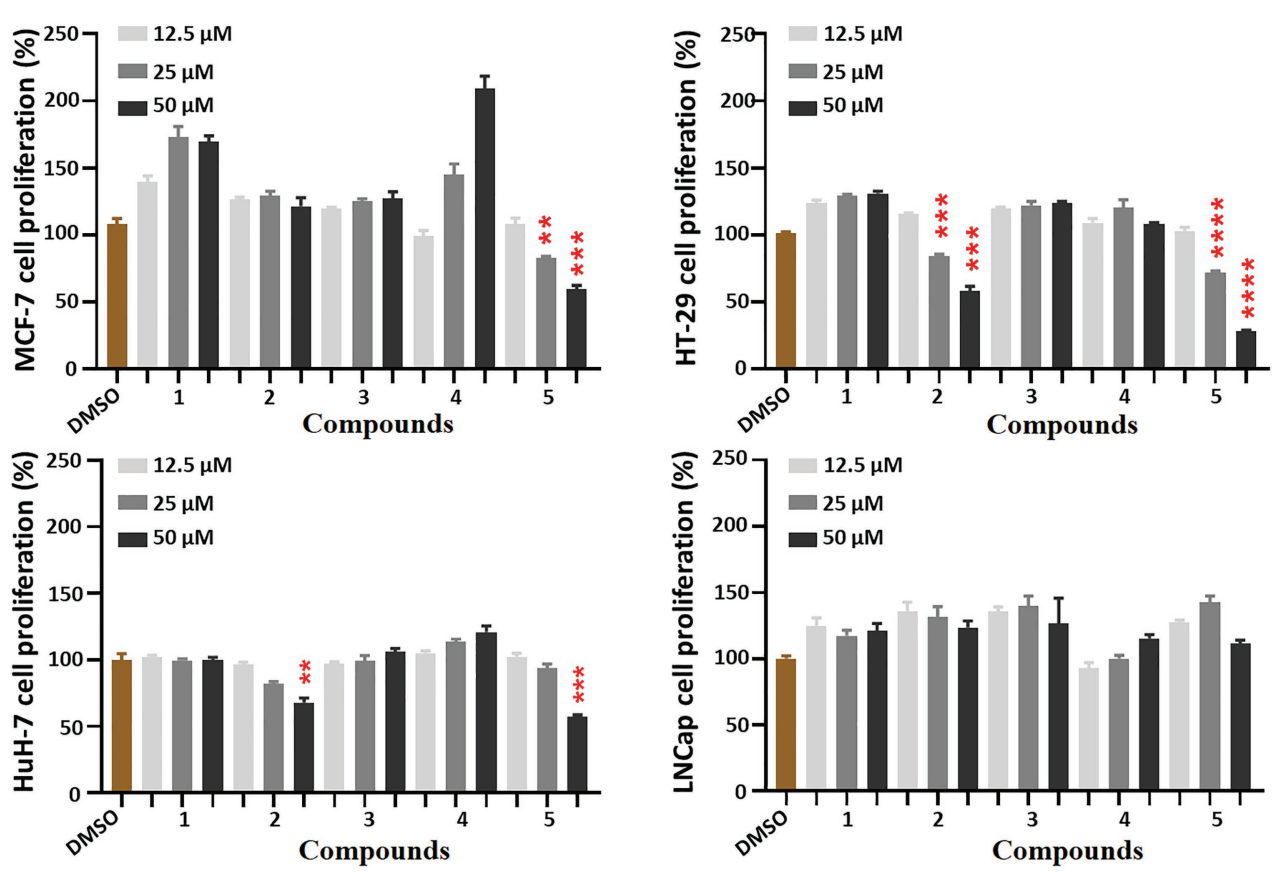

FIGURE 4 | Antiproliferative effects of compounds 1-5 against four cancer cells. Cells were treated with five compounds in a dose-course (12.5, 25, and 50 $\mu$ M) for $48 \mathrm{~h}$, which were analyzed by MTT assays to compare the cell proliferation levels. All the bar graphs represent mean \pm SEM of three independent experiments. $* * p<0.01, * * * p<0.001, * * * * p<0.0001$ vs. the DMSO group.

be found by the HMBC correlations of the hydroxy at $\delta_{\mathrm{H}} 8.92$ $\mathrm{s}$ to $\mathrm{C}-19\left(\delta_{\mathrm{C}} 115.2 \mathrm{~d}\right)$. By detailed analysis of its heteronuclear single quantum correlations (HSQC), correlation spectroscopy (COSY), heteronuclear multiple-bond correlation (HMBC), and nuclear overhauser effect (NOESY) spectroscopic data
(Supplementary Table S1 of the Supporting Information), the structure and relative configuration of the compound 2 were determined. The absolute configuration of compound 2 was assigned to be identical to that of compound $\mathbf{1}$ based on their similar specific rotations and ECD data. Compound 2 was 


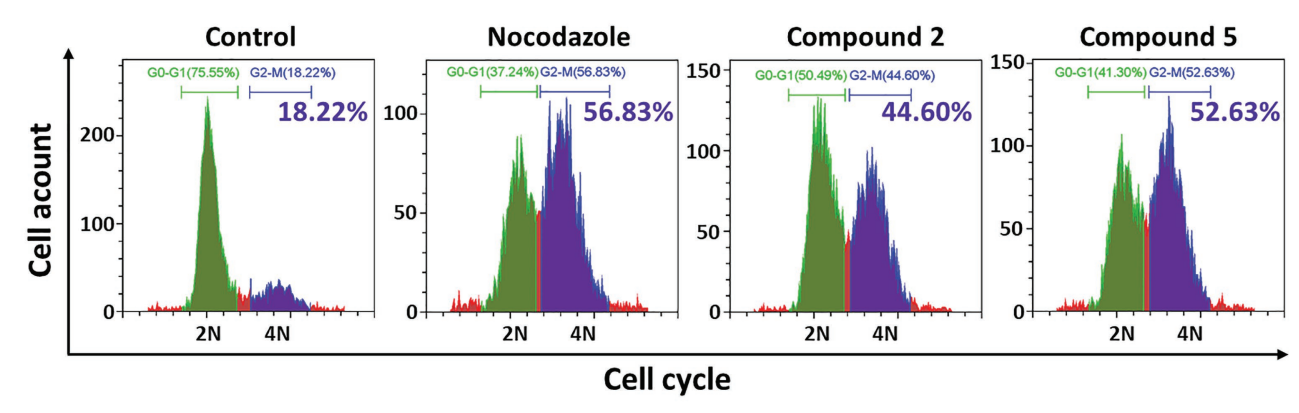

FIGURE 5 | Effects of compounds 2 and $\mathbf{5}$ on cell cycle by flow cytometry. HT-29 cells were treated with compound $\mathbf{2}(50 \mu \mathrm{M}, 48 \mathrm{~h})$ or $\mathbf{5}$ (30 $\mu \mathrm{M}, 48 \mathrm{~h})$, which were stained with DAPI for the following cell cycle FCM assay. The blue part indicated the cells in G0-G1 phase, the green part showed the G2-M phase cells, and the green numbers showed the G2-M phase proportion.
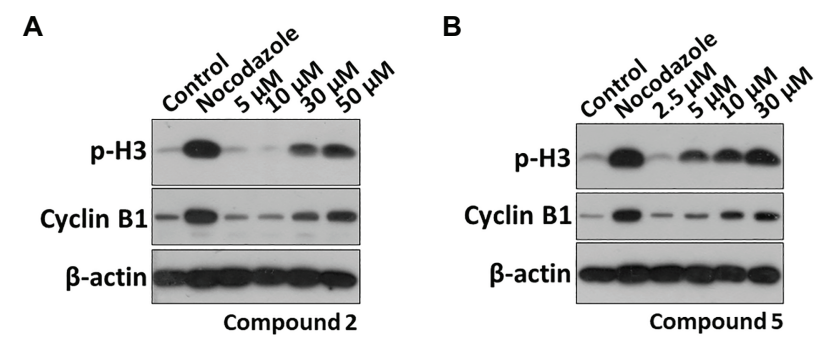

FIGURE 6 | Effects of compounds 2 and $\mathbf{5}$ on the expression of M phase marker proteins. HT29 cells were treated with (A) compound $\mathbf{2}(5,10,30$, and $50 \mu \mathrm{M})$ or $\mathbf{( B )}$ compound $\mathbf{5}(2.5,5,10$, and $30 \mu \mathrm{M})$ for $48 \mathrm{~h}$. The $\mathrm{p}-\mathrm{H} 3$ and Cyclin B1 protein levels were analyzed by Western blot (WB).

then established as 18-O-demethyl derivate of sorbiallisatol A, and named sorbicatechol D.

Hybrid sorbicillinoids are derived from either a Diels-Alder or a Michael reaction of a monomeric sorbicillinoid diene and a second non-sorbicillinoid dienophile (Meng et al., 2016). Noteworthily, compounds $\mathbf{1}$ and $\mathbf{2}$ are two novel hybrid sorbicillinoids derived from dihydrosorbicillinols which were very rarely in nature. Their biogenetic origin might be involved ferulic acid and 2',3'-dihydrosorbicillinol via an intermolecular DielsAlder condensation followed by a decarboxylation (Peng et al., 2014).

By comparison of NMR spectroscopic data with those published in the literatures, three known compounds were determined to be sohirnone A (3), 2',3'-dihydrosorbicillin (4; Maskey et al., 2005), and sorbicillin (5; Trifonov et al., 1983).

All five isolates were subjected to the preliminary screening tests for antiproliferative activity against MCF-7, HT-29, HuH-7, and LNCap tumor cells. Compounds 2 and $\mathbf{5}$ could inhibit the proliferation of HT-29 cells in a dose-dependent manner (Figure 4).

Interestingly, after treatment by compounds 2 and 5, many HT-29 cells became more rounded and less adherent under the microscope, which suggested cell cycle was disrupted and resulted in $\mathrm{M}$-phase arresting. Therefore, further investigation of the cell cycle was conducted by flow cytometry. As expected, they significantly blocked 40.96 and $41.69 \%$ tumor cells in G2-M phase, respectively (Figure 5). Therefore, compounds 2 and 5 could blocked HT-29 cells in G2-M phase.
Phosphorylation of histone $\mathrm{H} 3(\mathrm{p}-\mathrm{H} 3)$ is one of the methods of histone modification. It occurs at specific periods and chromosomal sites during mitosis and meiosis. Cyclin B1 also plays an important role in cell cycle regulation. The overexpression of cyclinB1 can promote $\mathrm{G} 2 / \mathrm{M}$ phase conversion and even lead to uncontrolled cell proliferation and malignant transformation (Hartwell and Kastan, 1994; Hwang et al., 1995). Therefore, the expression of $\mathrm{M}$ phase markers $\mathrm{p}-\mathrm{H} 3$ and cyclin B1 was further detected. As shown in Figure 6, they could significantly increase the protein levels of $\mathrm{p}-\mathrm{H} 3$ and cyclin B1 in a dose-dependent effect, confirming compounds 2 and 5 indeed induced $\mathrm{M}$ phase arresting. The effective concentrations of compounds 2 and 5 were 30 and $5 \mu \mathrm{M}$, respectively.

\section{CONCLUSION}

From the deep-sea-derived Penicillium allii-sativi MCCC 3A00580, five sorbicillinoids (1-5) were obtained. Compounds $\mathbf{1}$ and $\mathbf{2}$ are two novel hybrid dihyrosorbicillinoids. While compounds 3-5 are three known monomeric sorbicillinoids. Although several examples were found for monomeric, dimeric, and trimeric sorbicillinoids in which C-2'/C-3' double bonds were reduced, compounds $\mathbf{1}$ and $\mathbf{2}$ are the first two examples for hybrid sorbicillinoids. Therefore, the discovery of compounds 1 and $\mathbf{2}$ has expanded the diversity and complexity of sorbicillinoids. Compounds 2 and 5 could inhibit HT-29 tumor cells in a good dose-dependent manner. They significantly induced cell cycle G2-M phase arresting by increasing the protein levels of $\mathrm{p}-\mathrm{H} 3$ and cyclin $\mathrm{B} 1$.

\section{DATA AVAILABILITY STATEMENT}

The raw data supporting the conclusions of this article will be made available by the authors, without undue reservation.

\section{AUTHOR CONTRIBUTIONS}

C-LX performed chemical investigations. DZ conducted biological experiments. TL, Z-HH, and Q-XY assisted C-LX's chemical 
experiments. QC assisted DZ's bioactive experiments. X-KZ, $\mathrm{X}-\mathrm{WY}$, and H-FC initiated and oversaw all research. All authors contributed to the article and approved the submitted version.

\section{FUNDING}

This work was financially supported by the National Natural Science Foundation of China (21877022), the COMRA program

\section{REFERENCES}

Abe, N., Sugimoto, O., Tanji, K. -I., and Hirota, A. (2000). Identification of the quinol metabolite "sorbicillinol", a key intermediate postulated in bisorbicillinoid biosynthesis. J. Am. Chem. Soc. 122, 12606-12607. doi: 10.1021/ja0030131

Abe, N., Yamamoto, K., Arakawa, T., and Hirota, A. (2001). The biosynthesis of bisorbicillinoids: evidence for a biosynthetic route from bisorbicillinol to bisorbibutenolide and bisorbicillinolide. Chem. Commun. 2001, 23-24. doi: 10.1039/B007181L

Fahad, A. A., Abood, A., Fisch, K. M., Osipow, A., Davison, J., Avramović, M., et al. (2013). Oxidative dearomatisation: the key step of sorbicillinoid biosynthesis. Chem. Sci. 5, 523-527. doi: 10.1039/c3sc52911h

Harned, A. M., and Volp, K. A. (2011). The sorbicillinoid family of natural products: isolation, biosynthesis, and synthetic studies. Nat. Prod. Rep. 28, 1790-1810. doi: 10.1039/clnp00039j

Hartwell, L. H., and Kastan, M. B. (1994). Cell cycle control and cancer. Science 266, 1821-1828. doi: 10.1126/science.7997877

Hwang, A., Maity, A., McKenna, W. G., and Muschel, R. J. (1995). Cell cycledependent regulation of the cyclin B1 promoter. J. Biol. Chem. 270, 28419-28424. doi: $10.1074 /$ jbc.270.47.28419

Kahlert, L., Bassiony, E. F., Cox, R. J., and Skellam, E. J. (2020). Diels-Alder reactions during the biosynthesis of sorbicillinoids. Angew. Chem. Int. Ed. Eng. 59, 5816-5822. doi: 10.1002/anie.201915486

Maskey, R. P., Grun-Wollny, I., and Laatsch, H. (2005). Sorbicillin analogues and related dimeric compounds from Penicillium notatum. J. Nat. Prod. 68, 865-870. doi: 10.1021/np040137t

Meng, J., Gu, G., Dang, P., Zhang, X., Wang, W., Dai, J., et al. (2019). Sorbicillinoids from the fungus Ustilaginoidea virens and their phytotoxic, cytotoxic, and antimicrobial activities. Front. Chem. 7:435. doi: 10.3389/fchem.2019.00435

Meng, J., Wang, X., Xu, D., Fu, X., Zhang, X., Lai, D., et al. (2016). Sorbicillinoids from fungi and their bioactivities. Molecules 21, 715-733. doi: 10.3390/ molecules21060715

Niu, S., Fan, Z. W., Xie, C. L., Liu, Q., Luo, Z. H., Liu, G., et al. (2017). Spirograterpene A, a tetracyclic spiro-diterpene with a fused 5/5/5/5 ring system from the deep-sea-derived fungus Penicillium granulatum MCCC 3A00475. J. Nat. Prod. 80, 2174-2177. doi: 10.1021/acs.jnatprod.7b00475
(DY135-B2-08), and the Xiamen Southern Oceanographic Center (17GYY002NF02).

\section{SUPPLEMENTARY MATERIAL}

The Supplementary Material for this article can be found online at: https://www.frontiersin.org/articles/10.3389/fmicb.2020.636948/ full\#supplementary-material

Niu, S., Xie, C. L., Xia, J. M., Liu, Q. M., Peng, G., Liu, G. M., et al. (2020). Botryotins $\mathrm{A}-\mathrm{H}$, tetracyclic diterpenoids representing three carbon skeletons from a deep-sea-derived Botryotinia fuckeliana. Org. Lett. 22, 580-583. doi: 10.1021/acs.orglett.9b04332

Peng, J., Zhang, X., Du, L., Wang, W., Zhu, T., Gu, Q., et al. (2014). Sorbicatechols $\mathrm{A}$ and $\mathrm{B}$, antiviral sorbicillinoids from the marine-derived fungus Penicillium chrysogenum PJX-17. J. Nat. Prod. 77, 424-428. doi: $10.1021 / \mathrm{np} 400977 \mathrm{e}$

Trifonov, L. S., Bieri, J. H., Prewo, R., Dreiding, A. S., Hoesch, L., and Rast, D. M. (1983). Isolation and structure elucidation of three metabolites from Verticillium intertextum: sorbicillin, dihydrosorbicillin and bisvertinoquinol. Tetrahedron 39, 4243-4256. doi: 10.1016/S0040-4020(01)88647-6

Xie, C. L., Chen, R., Yang, S., Xia, J. M., Zhang, G. Y., Chen, C. H., et al. (2019a). Nesteretal A, a novel class of cage-like polyketide from marinederived actinomycete Nesterenkonia halobia. Org. Lett. 21, 8174-8177. doi: 10.1021/acs.orglett.9b02634

Xie, C. L., Xia, J. M., Lin, T., Lin, Y. J., Lin, Y. K., Xia, M. L., et al. (2019b). Andrastone A from the deep-sea-derived fungus Penicillium allii-sativi acts as an inducer of caspase and RXRa-dependent apoptosis. Front. Chem. 7:692. doi: 10.3389/fchem.2019.00692

Yang, X. W., Peng, K., Liu, Z., Zhang, G. Y., Li, J., Wang, N., et al. (2013). Strepsesquitriol, a rearranged zizaane-type sesquiterpenoid from the deepsea-derived actinomycete Streptomyces sp. SCSIO 10355. J. Nat. Prod. 76, 2360-2363. doi: 10.1021/np400923c

Conflict of Interest: The authors declare that the research was conducted in the absence of any commercial or financial relationships that could be construed as a potential conflict of interest.

Copyright (C) 2021 Xie, Zhang, Lin, He, Yan, Cai, Zhang, Yang and Chen. This is an open-access article distributed under the terms of the Creative Commons Attribution License (CC BY). The use, distribution or reproduction in other forums is permitted, provided the original author(s) and the copyright owner(s) are credited and that the original publication in this journal is cited, in accordance with accepted academic practice. No use, distribution or reproduction is permitted which does not comply with these terms. 